J. AMER. SOC. HoRT. SCI. 117(6):981-984. 1992.

\title{
The Genetics of the Juvenile Phase in Avocado and its Application for Breeding
}

\author{
Uri Lavi \\ Department of Fruit Tree Genetics and Breeding, Agricultural Research Organization, The Volcani \\ Center, P.O. Box 6, Bet Dagan 50250, Israel \\ Emanuel Lahav and Chemda Degani \\ Department of Fruit Trees, Agricultural Research Organization, The Volcani Center, P.O. Box 6, \\ Bet Dagan 50250, Israel \\ Shmuel Gazit \\ Department of Horticulture, Faculty of Agriculture, The Hebrew University of Jerusalem, P.O. Box \\ 12, Rehovot 76100, Israel
}

Additional index words. flowering age, yield age

Abstract. Avocado (Persea americana Mill.) progeny that originated from 11 crosses (both self-pollinations and crosses between cultivars) were evaluated for the length of their juvenile period. Time to first flowering, "flowering age," and time to first fruit production, "fruiting age," were recorded for each progeny. The mean values for both ages, the SD, and the progeny distribution were calculated. Significant statistical differences in flowering age and fruiting age between various progeny populations were detected. No differences were detected between self-pollinated plants and crosses. The time until first flowering was found to be the limiting factor in evaluation of seedlings.

The developmental period when flowering does not occur and cannot be induced by normal flower-initiating treatments is called the juvenile phase and exists in all woody plants. This period lasts up to 40 years in certain forest trees (Hackett, 1985). After this phase, the tree is considered to have attained the adult or sexually mature condition. The length of the juvenile period is influenced by environmental and genetic factors. The change from the juvenile to the mature phase may be associated with morphological changes, such as leaf and branch characteristics (Schaffalitzky de Muckadell, 1959; Sweet and Wells, 1974). This change is controlled by developmental stage and varies in length among species (Hackett, 1985). It is noteworthy that juvenile traits may continue for several years after the first flowering season.

The length of the juvenile period strongly affects the breeding efficiency of woody perennials. A long juvenile period is considered to be a major obstacle in breeding improved cultivars (Hansche, 1983; Hansche and Beres, 1980; Sherman and Lyrene, 1983). Many measures have been taken to shorten the juvenile period in various fruit trees (Hackett, 1985), including avocado (Lahav et al., 1986).

Some evidence points to the role of genetic factors in controlling the length of the juvenile period. For example, Johnson (1940) identified a single dominant gene responsible for early flowering of Betula pubescens Ehrh. Visser et al. (1976) analyzed 22 apple (Malus domestica Borkh.) and 33 pear (Pyrus communis L.) progenies and detected highly significant general combining ability and nonsignificant specific combining ability variances for the juvenile period, suggesting that the length of

Received for publication 30 Dec. 1991. Accepted for publication 27 Apr. 1992. Contribution from the Agricultural Research organization, The Volcani Center, Bet Dagan, Israel. no. 3395-E. 1991 series. The Israel Fruit Board provided financial support for this research. We express our gratitude to the Akko and Bet Dagan Horticultural Experiment Stations and in particular to D.N. Zamet, A. Chapnik, and M. Cohen for their highly competent assistance. The cost of publishing this paper was defrayed in part by the payment of page charges. Under postal regulations, this paper therefore must be hereby marked advertisement solely to indicate this fact. the juvenile period in these species is a quantitative character having a significant additive component.

Relative to other fruit trees, the juvenile period in avocado is long, extending up to $\geq 15$ years before first flowering (Bergh, 1986). Several measures have been attempted to shorten the juvenile period in avocado. Topworking has been tested on a limited scale but has not enhanced precocity appreciably (Bergh, 1986 and our unpublished results; Sanchez Colin et al., 1987; Sedgley and Alexander, 1983). Bending down seedling branches failed in California and Israel (unpublished results). Growth retardants, such as paclobutrazol, have produced inconclusive results so far (unpublished data). Early autumn girdling of avocado seedlings 3 years after planting significantly increased the percentage of flowering and fruit-setting seedlings the following spring (Lahav et al., 1986).

The juvenile period in avocado seedlings can be shortened significantly by choice of parents. For example, 'Pinkerton' and 'Gwen' have produced very precocious offspring, including a few that set fruit 2 years after field planting (B.O. Bergh, personal communiation). In this study, comparison of the behavior of progeny resulting from various crosses was carried out. The results point toward genetic effects on the length of the juvenile period in avocado.

\section{Materials and Methods}

The parent and progeny plots were located at the Akko Experiment Station in western Galilee, Israel. Seeds were collected from trees caged under a net, with bees used as the pollen vector. Crosses between different cultivars as well as self-pollinations were performed (Table 1) (Lavi et al., 1991). The number of progeny from the various crosses varied from 46 to 387, for a total of 1392 seedlings. Different trees of certain cultivars were used as parents for the various crosses due to the need for geographical proximity required for caging the trees. The harvested seeds were sown in a nursery and 1 year later were transplanted into breeding plots. The progeny of each cage was planted randomly in a block. Agrotechnical practices were similar to those carried out in commercial avocado plantations: 
Table 1. Length in years of the juvenile period in 11 avocado progeny populations.

\begin{tabular}{|c|c|c|c|c|c|c|c|c|c|}
\hline \multirow[b]{2}{*}{ Cross $^{2}$} & \multirow[b]{2}{*}{$\begin{array}{c}\text { Progeny } \\
\text { (no.) }\end{array}$} & \multicolumn{4}{|c|}{ Flowering age } & \multicolumn{4}{|c|}{ Fruiting age } \\
\hline & & Mean & SD & Range & $\begin{array}{c}\text { Flowered } \\
(\%)\end{array}$ & Mean & SD & Range & $\begin{array}{c}\text { Fruited } \\
(\%)\end{array}$ \\
\hline 'Rosh Hanikra II' X 'Ettinger' & 51 & $4.3^{y}$ & 0.7 & $3-7$ & 90.2 & $5.4^{x}$ & 1.1 & $3-7$ & 62.7 \\
\hline 'Tova' x 'Fuerte' & 48 & 5.0 & 1.5 & $3-14$ & 91.8 & 5.6 & 2.0 & $4-14$ & 37.7 \\
\hline 'Hass' x 'Fuerte' & 123 & 5.8 & 1.7 & $3-10$ & 86.1 & 6.3 & 1.9 & $4-11$ & 70.8 \\
\hline 'Ettinger' (selfed) & 235 & 5.9 & 1.1 & $4-8$ & 70.7 & 6.9 & 0.8 & $5-8$ & 42.1 \\
\hline 'Ettinger' $x$ 'Tova' & 62 & 6.2 & 1.7 & $3-10$ & 91.9 & 7.0 & 2.0 & $4-10$ & 83.9 \\
\hline 'Tova' x 'Regina' & 54 & 6.2 & 0.9 & $5-7$ & 88.9 & 6.5 & 0.8 & $5-7$ & 79.6 \\
\hline 'Hass' x 'Ettinger' & 46 & 6.4 & 1.3 & $4-8$ & 93.6 & 6.9 & 1.2 & $5-8$ & 89.2 \\
\hline 'Anaheim' (selfed) & 61 & 6.5 & 0.6 & $5-7$ & 68.9 & 6.5 & 0.7 & $5-7$ & 32.8 \\
\hline 'Tova' x 'Ettinger' & 387 & 7.0 & 2.1 & $3-11$ & 77.4 & 7.0 & 1.9 & $3-10$ & 37.7 \\
\hline 'Horshim' x 'Tova' & 240 & 7.5 & 1.9 & $4-10$ & 53.3 & 7.5 & 1.3 & $5-9$ & 19.2 \\
\hline 'Nabal' (selfed) & 85 & 8.6 & 1.5 & $6-10$ & 40.1 & 9.4 & 1.0 & $7-10$ & 29.4 \\
\hline
\end{tabular}

${ }^{\mathrm{z}}$ Order is from low to high mean of flowering age, calculating only for seedlings that flowered and yielded during the experiment.

${ }^{\mathrm{y}}$ Data refer to the seedlings that flowered during the experiment.

${ }^{\mathrm{x}}$ Data refer to the seedlings that fruited during the experiment.

irrigation $\left(\approx 4000 \mathrm{~m}^{3} \cdot \mathrm{ha}^{-1}\right)$ twice a week by drip and fertilization with $20 \mathrm{ppm}$ of $\mathrm{N}$ as $\mathrm{NH}_{4} \mathrm{NO}_{3}$, herbicides were used as necessary, and all seedlings were girdled every autumn from the third year onward.

To distinguish between hybrids and self-pollinated seedlings, the progeny were characterized by isozyme analyses of leaf tissue for the following enzyme systems: leucine aminopeptidase (LAP; EC 3.4.11.1) (Degani et al., 1986), malate dehydrogenase (MDH; EC 1.1.1.37) (Degani and Gazit, 1984), phosphoglucoisomerase (PGI; EC 5.3.1.9) (Goldring et al., 1985), phosphoglucomutase (PGM; EC 2.7.5.1) (Torres et al., 1978), and triosephosphate isomerase (TPI; EC 5.3.1.1) (Goldring et al., 1987). Progeny analysis by isozymes sometimes detected alleles of "outside the net" origin; these individuals were not included in the present analysis. The analysis was based exclusively on individuals that could be shown to result from either crossing with the pollen donor present in the net cage or to selfpollinations. However, it is possible that not all of the individuals having the expected isozyme patterns are progeny of the planned pollen donor parent.

First flowering and first fruit production were defined when the first inflorescence or the first fruit were detected, respectively. Usually first flowering or first fruit production were expressed in a few inflorescences or fruits on the seedling.

Statistical analyses were carried out by PROC CATMOD of the SAS software (SAS, 1985). Significance was determined at $P=0.01$.

\section{Results}

The mean flowering age ranged between 4.3 years for the progeny of 'Rosh-Hanikra II' $\times$ 'Ettinger' and 8.6 years for the selfpollinated progeny of 'Nabal' (Table 1). Flowering age ranged from 3 to 11 years (one record of first flowering after 14 years); fruiting age ranged from 4 to 11 years (one seedling yielded 14 years after planting). The SD in flowering age (Table 1) ranged from 0.6 for the self-pollinated progeny of 'Anaheim' to 2.1 for the progeny of 'Tova' $\times$ 'Ettinger'. In fruiting age, the smallest SD was 0.7 for the self-pollinated progeny of 'Anaheim' and 2.0 for the progeny of 'Ettinger' $\times$ 'Tova' and 'Tova' $\times$ 'Fuerte'.

No seedlings flowered (Table 2) or fruited (Table 3) earlier than 3 years after planting and only up to $4.2 \%$ did so at the age of 3 years. In most populations, about half of the seedlings flowered after 5 to 6 years and fruited after 6 to 7 years. In most cases, records were taken for up to 10 years after planting, and in one case ('Tova' $\times$ 'Fuerte'), the progeny were kept for 14 years. A significant portion of each progeny did not flower and/or fruit during the 10 years. The flowering portion varied between $6.5 \%$ in the progeny of 'Hass' $\times$ 'Ettinger' and $60 \%$ in the self-pollinated offspring of 'Nabal'. The portion that did not fruit varied between $11 \%$ of the progeny of 'Hass' $\times$ 'Ettinger' to $81 \%$ of the progeny of 'Horshim' $\times$ 'Tova'.

Taking these portions into consideration, we have also analysed the differences between the progeny of various crosses by assigning the value of 15 years to those seedlings that did not flower or fruit during the experiment. This assignment, although probably an underestimate (those seedlings could flower and fruit after 15 years or more, although some of them could do it between 10 to 15 years), takes into consideration all the seedlings and not only those that flowered and fruited. According to this analysis (Table 4), the average earliest flowering age is 5.3 for the progeny of 'Rosh Hanikra II' $\times$ 'Ettinger' and the latest is 12.4 years for the self-pollinated progeny of 'Nabal'. The average earliest age to fruiting is 7.9 years for the progeny of 'Hass' $\times$ 'Ettinger' and the average latest age to fruiting is 13.5 years for the progeny of 'Horshim' $\times$ 'Tova'. The statistical significance of the difference between the progeny of the various crosses in both flowering age and fruiting age are also given (Table 4).

To assess the impact of the length of the juvenile period (flowering age) on the time needed for the first fruit production (fruit age), the difference between fruiting age and flowering age was calculated for each seedling (Table 5). Referring only to those seedlings that both flowered and fruited, $55 \%$ to $95 \%$ of the seedlings, first fruiting occured in the same year as flowering (zero difference). Fewer than 5\% of the seedlings showed a difference of 4 to 7 years. About $5 \%$ to $35 \%$ of the seedlings fruited either 1 or 2 years after first flowering.

In most cases, the seedlings that flowered and did not fruit flowered during the last years of the experiment and probably fruiting was not detected before the plot was uprooted (at 10 years). However, in the case of 'Rosh Hanikra II' $\times$ 'Ettinger', of the $27.5 \%$ seedlings that flowered and did not fruit, $\approx 85 \%$ flowered during the first 5 years. Had first fruiting followed first flowering within 1 to 3 years, these seedlings should have fruited. This case was the only cross where first flowering was not sufficient for first fruiting within 1 to 3 years. 
Table 2. Cumulative flowering age in 11 avocado progeny populations given as percentages of the progeny for each year after sowing (blank spaces indicate no data available).

\begin{tabular}{|c|c|c|c|c|c|c|c|c|c|c|c|c|}
\hline \multirow[b]{2}{*}{ Cross } & \multicolumn{10}{|c|}{ Year } & \multirow{2}{*}{$\begin{array}{c}\text { Not } \\
\text { flowering }\end{array}$} & \multirow{2}{*}{$\begin{array}{l}\text { Total } \\
\text { (no.) }\end{array}$} \\
\hline & 3 & 4 & 5 & 6 & 7 & 8 & 9 & 10 & 11 & 14 & & \\
\hline 'Rosh Hanikra II' x 'Ettinger' & 3.9 & 70.6 & 86.3 & 86.3 & 90.2 & 90.2 & 90.2 & 90.2 & \multirow{4}{*}{89.7} & \multirow{3}{*}{91.8} & 9.8 & 51 \\
\hline 'Tova' x 'Fuerte' & 4.2 & 37.5 & 77.1 & 81.3 & 83.4 & 87.6 & 87.6 & 89.7 & & & 8.2 & 48 \\
\hline 'Hass' x 'Fuerte' & 0.8 & 18.7 & 50.4 & 62.5 & 66.6 & 76.4 & 83.7 & 86.1 & & & 13.9 & 123 \\
\hline 'Ettinger' (selfed) & 0.0 & 4.7 & 31.4 & 43.9 & 66.9 & 70.7 & 70.7 & 70.7 & & & 29.3 & 235 \\
\hline 'Ettinger' $x$ 'Tova' & 3.2 & 22.5 & 43.5 & 49.9 & 74.1 & 83.8 & 83.8 & 91.9 & & & 8.1 & 62 \\
\hline 'Tova' x 'Regina' & 0.0 & 0.0 & 25.9 & 42.6 & 88.9 & 88.9 & 88.9 & 88.9 & & & 11.1 & 54 \\
\hline 'Hass' x 'Ettinger' & 0.0 & 8.7 & 19.6 & 54.4 & 56.6 & 93.6 & & & & & 6.4 & 46 \\
\hline 'Anaheim' (selfed) & 0.0 & 0.0 & 3.3 & 27.9 & 68.9 & 68.9 & 68.9 & 68.9 & & & 31.1 & 61 \\
\hline 'Tova' x 'Ettinger' & $\begin{array}{l}0.0 \\
1.8\end{array}$ & 14.2 & 24.5 & 31.7 & 46.2 & 46.7 & 70.7 & 76.9 & 77.4 & & 22.6 & 387 \\
\hline 'Horshim' x 'Tova' & 0.0 & 1.7 & 11.3 & 19.2 & 25.4 & 35.4 & 41.6 & 53.3 & & & 46.7 & 240 \\
\hline \multirow[t]{2}{*}{ 'Nabal' (selfed) } & 0.0 & 0.0 & 0.0 & 7.1 & 9.5 & 17.7 & 22.9 & 40.1 & & & 59.9 & 85 \\
\hline & & & & & & & & & & \multicolumn{2}{|r|}{ Total: } & 1392 \\
\hline
\end{tabular}

Table 3. Cumulative fruiting age in 11 avocado progeny populations given as percentages of the progeny for each year after sowing (blank spaces indicate no data available).

\begin{tabular}{|c|c|c|c|c|c|c|c|c|c|c|c|c|}
\hline \multirow[b]{2}{*}{ Cross } & \multicolumn{10}{|c|}{ Year } & \multirow{2}{*}{$\begin{array}{c}\text { Not } \\
\text { fruiting }\end{array}$} & \multirow{2}{*}{$\begin{array}{l}\text { Total } \\
\text { (no.) }\end{array}$} \\
\hline & 3 & 4 & 5 & 6 & 7 & 8 & 9 & 10 & 11 & 14 & & \\
\hline 'Rosh Hanikra II' x 'Ettinger' & 3.9 & 13.7 & 35.3 & 49.0 & 62.7 & 62.7 & 62.7 & 62.7 & & & 37.3 & 51 \\
\hline 'Tova' x 'Fuerte' & 0.0 & 27.1 & 54.2 & 54.2 & 60.4 & 64.6 & 66.7 & 72.9 & 72.9 & 75.0 & 25.0 & 48 \\
\hline 'Hass' x 'Fuerte' & 0.0 & 11.4 & 34.2 & 44.8 & 51.3 & 57.8 & 62.7 & 68.4 & 70.8 & & 29.2 & 123 \\
\hline 'Ettinger' (selfed) & 0.0 & 0.0 & 3.8 & 8.5 & 34.4 & 42.1 & 42.1 & 42.1 & & & 57.9 & 235 \\
\hline 'Ettinger' $\mathrm{x}$ 'Tova' & 0.0 & 3.2 & 27.4 & 37.1 & 56.5 & 62.9 & 64.5 & 83.9 & & & 16.1 & 62 \\
\hline 'Tova' x 'Regina' & 0.0 & 0.0 & 18.5 & 18.5 & 79.6 & 79.6 & 79.6 & 79.6 & & & 20.4 & 54 \\
\hline 'Hass' $\mathrm{x}$ 'Ettinger' & 0.0 & 0.0 & 10.9 & 39.2 & 39.2 & 89.2 & 89.2 & 89.2 & & & 10.8 & 46 \\
\hline 'Anaheim' (selfed) & 0.0 & 0.0 & 3.3 & 16.4 & 32.8 & 32.8 & 32.8 & 32.8 & & & 67.2 & 61 \\
\hline 'Tova' $x$ 'Ettinger' & 1.0 & 6.9 & 10.5 & 20.1 & 24.2 & 24.7 & 37.4 & 37.7 & & & 62.3 & 387 \\
\hline 'Horshim' x 'Tova' & 0.0 & 0.0 & 1.3 & 6.3 & 8.8 & 14.6 & 19.2 & 19.2 & & & 80.8 & 240 \\
\hline \multirow[t]{2}{*}{ 'Nabal' (selfed) } & 0.0 & 0.0 & 0.0 & 0.0 & 2.3 & 7.0 & 8.2 & 29.4 & & & 70.6 & 85 \\
\hline & & & & & & & & & & & Total: & 1392 \\
\hline
\end{tabular}

Table 4. Statistical differences among 11 avocado progeny populations in flowering age and fruiting age in various years.

\begin{tabular}{|c|c|c|c|c|c|c|c|c|c|c|}
\hline \multirow[b]{2}{*}{ Cross $^{z}$} & \multicolumn{5}{|c|}{ Flowering age (yr) } & \multicolumn{5}{|c|}{ Fruiting age } \\
\hline & 4 & 5 & 6 & 7 & Mean & 4 & 5 & 6 & 7 & Mean \\
\hline 'Rosh Hanikra II' $x$ 'Ettinger' & $a^{y}$ & a & a & $\mathrm{a}$ & $5.3^{x} \mathrm{f}$ & $a b$ & $a b$ & $\mathrm{a}$ & $a b$ & $9.0^{\mathrm{w}} \mathrm{b}$ \\
\hline 'Tova' x 'Fuerte' & $\mathrm{b}$ & a & $a b$ & $a b$ & $5.9 \mathrm{f}$ & a & a & a & $\mathrm{ab}$ & $8.1 \mathrm{~b}$ \\
\hline 'Ettinger' $x$ 'Tova' & bc & bc & c & $a b c$ & $6.8 \mathrm{fe}$ & bc & $\mathrm{bc}$ & $\mathrm{ab}$ & $\mathrm{ab}$ & 8.3 \\
\hline 'Hass' x 'Fuerte' & bcd & $\mathrm{b}$ & bc & bc & $7.1 \mathrm{def}$ & $a b$ & $a b$ & a & $b$ & 8.9 \\
\hline 'Hass' $x$ 'Ettinger' & $\mathrm{cd}$ & de & c & $\mathrm{cd}$ & $7.1 \mathrm{def}$ & bc & cde & $a b$ & bc & 7.9 \\
\hline 'Tova' x ‘Regina' & d & $\mathrm{d}$ & de & $\mathrm{a}$ & $7.2 \mathrm{def}$ & bc & bcd & $\mathrm{b}$ & $\mathrm{a}$ & 8.3 \\
\hline 'Ettinger’' (selfed) & $\mathrm{d}$ & $\mathrm{cd}$ & $\mathrm{cd}$ & $\mathrm{bc}$ & $8.6 \mathrm{dce}$ & c & $\mathrm{cd}$ & c & c & 11.6 \\
\hline 'Tova' x 'Ettinger' & $\mathrm{cd}$ & $\mathrm{d}$ & e & $\mathrm{d}$ & $8.7 \mathrm{dc}$ & bc & de & $b$ & c & 11.9 \\
\hline 'Anaheim' (selfed) & e & ef & ef & $a b c$ & $9.2 \mathrm{bc}$ & $\mathrm{bc}$ & de & bc & c & 12.2 \\
\hline 'Horshim' x ‘Tova' & d & ef & f & e & $11.0 \mathrm{ab}$ & c & $\mathrm{e}$ & c & d & 13.5 \\
\hline 'Nabal' (selfed) & $\mathrm{d}$ & f & $\mathrm{g}$ & f & $12.4 \mathrm{a}$ & $\mathrm{bc}$ & e & c & d & $13.4 \mathrm{a}$ \\
\hline
\end{tabular}

${ }^{\mathrm{z}}$ Order is from low to high mean of flowering age, considering all seedlings in a cross.

${ }^{\mathrm{y}}$ Within years, progeny with a common letter do not differ significantly in flower or fruiting age.

${ }^{\mathrm{x}}$ Average flowering age: seedlings that did not flower during the experiment were assigned a flowering age of 15 years.

${ }^{\text {w }}$ Average yield age: seedling that did not fruit during the experiment were assigned a fruiting age of 15 years.

\section{Discussion}

The juvenile period is well-known to be affected by several environmental factors, including nutrition, light, and others (Hackett, 1985). Although we cannot rule out the possibility that in our experiment differences in the juvenile period among the 11 populations were caused by environmental factors, we believe that a major cause of the differences was their genetic content. Although each progeny population was planted in a certain row(s), all populations were grown in the same orchard and received the same agrotechnical practices.

A difference by a factor of two between the earliest ('Rosh Hanikra II' $\times$ 'Ettinger' 5.3 years) and the latest ('Nabal' selfpollinations 12.4 years) mean flowering age probably has a major genetic origin that is quantitatively controlled.

Statistical analysis shows clearly that the various progeny populations differ significantly in flowering and fruiting ages (Table 4). Although there were some variations when the var- 
Table 5. Distribution of the differences in years between flowering age and fruiting age in 11 avocado progeny populations.

\begin{tabular}{|c|c|c|c|c|c|c|c|c|}
\hline \multirow[b]{2}{*}{ Cross $^{\mathbf{z}}$} & \multicolumn{8}{|c|}{$\begin{array}{l}\text { Number of years between } \\
\text { flowering age and yield age }\end{array}$} \\
\hline & 0 & 1 & 2 & 3 & 4 & 5 & 7 & $\begin{array}{c}\text { Significance } \\
\text { of the } \\
\text { average }\end{array}$ \\
\hline 'Rosh Hanikra II' X 'Ettinger' & $54.9^{y}$ & 17.6 & 17.6 & 9.8 & 0.0 & 0.0 & 0.0 & $a^{\mathbf{x}}$ \\
\hline 'Tova' x 'Fuerte' & 77.1 & 8.3 & 4.2 & 6.2 & 0.0 & 4.2 & 0.0 & $a b$ \\
\hline 'Hass' X 'Fuerte' & 76.4 & 6.5 & 11.4 & 0.8 & 2.4 & 1.6 & 0.8 & $a b$ \\
\hline ‘Ettinger’ (selfed) & 74.5 & 6.8 & 13.6 & 4.2 & 0.9 & 0.0 & 0.0 & $a b c$ \\
\hline 'Ettinger' $x$ 'Tova' & 58.1 & 17.7 & 12.9 & 6.5 & 3.2 & 1.6 & 0.0 & a \\
\hline 'Tova' x 'Regina' & 83.3 & 13.0 & 3.7 & 0.0 & 0.0 & 0.0 & 0.0 & bcd \\
\hline 'Hass' $x$ 'Ettinger' & 73.9 & 13.0 & 10.9 & 2.2 & 0.0 & 0.0 & 0.0 & abcd \\
\hline 'Anaheim' (selfed) & 95.1 & 4.9 & 0.0 & 0.0 & 0.0 & 0.0 & 0.0 & d \\
\hline 'Tova' $x$ 'Ettinger' & 91.2 & 1.6 & 5.7 & 0.5 & 0.5 & 0.5 & 0.0 & bcd \\
\hline 'Horshim' $x$ 'Tova' & 92.9 & 3.3 & 1.3 & 1.3 & 0.8 & 0.4 & 0.0 & bcd \\
\hline 'Nabal' (selfed) & 91.8 & 4.7 & 3.5 & 0.0 & 0.0 & 0.0 & 0.0 & $\mathrm{~cd}$ \\
\hline
\end{tabular}

${ }^{\mathrm{z}}$ Order is as in Table 1 .

${ }^{\mathrm{y}}$ Percentage of the progeny.

${ }^{\mathrm{x}}$ Progeny having a common letter do not differ significantly.

ious populations in the different years were compared, the general picture is quite stable, distinguishing between populations having relatively early and late flowering and fruiting ages. No differences were detected between self-pollination and crosses between cultivars, meaning that probably there is no significant effect of heterozygosity level on the length of the juvenile period.

The progeny distribution in flowering and fruiting ages is of great importance for breeders. They are interested in obtaining the maximal number of yielding seedlings from a certain area in a certain time. Referring to the distribution, the breeder can predict the number of seedlings that should fruit in every year and make the relevant decisions. For example, at what age it will be advisable to uproot a plot and replant it. We suggest the following formula: $\mathrm{P}_{\mathrm{X}}(\mathrm{N} / \mathrm{X})+\mathrm{P}_{\mathrm{N}}-\mathrm{X}(\mathrm{N} / \mathrm{X})$, where $\mathrm{N}$ is the number of years planned for the project (for avocado $\approx 20$ to 30 years); $\mathrm{X}$ is the number of years of one cycle from planting to uprooting (for avocado, usually 6 to 14 years); $P_{X}$ is the cummulative fraction of trees that would yield in a given cycle; and $\mathrm{P}_{\mathrm{N}}-\mathrm{X}[\mathrm{N} / \mathrm{X}]$ is the fraction of trees that would yield in the remaining time: $[\mathrm{N}-\mathrm{X}(\mathrm{N} / \mathrm{X})]$. $\mathrm{N} / \mathrm{X}$ will be calculated as the closest whole number. The solution of $\mathrm{X}$ will be the one giving the maximal value. For example, based on our results (Table 2) and assuming $\mathrm{N}=30$ years, we calculated the optimal cycle for progeny of 'Rosh Hanikra II' $\times$ 'Ettinger' to be 5 years and for self-pollinated progeny of 'Nabal' to be 10 years. The expenses of uprooting and replanting are up to each breeder and are not considered here.

For most populations and for the majority of the seedlings, those that flowered in a certain year yielded the same year or the following year (Table 5). Only in a small fraction of the seedlings did several years pass between first flowering and first fruiting, pointing to the conclusion that the limiting factor in an avocado breeding program is indeed the time to first flowering. This assertion is in opposition to the assumption that a major obstacle for yield is the time from first flowering to first yield. We found that most seedlings that flowered and did not fruit during this experiment ( $4 \%$ to $40 \%$ of the populations, Tables 2 and 3) flowered after 7 years or more. Only in the progeny of 'Rosh Hanikra II' $\times$ 'Ettinger' was there a significant proportion of the population $(27 \%)$ that did not fruit within 3 years after first flowering.

We conclude that the choice of parents will strongly influence the efficiency of a breeding project.

\section{Literature Cited}

Bergh, B.O. 1986. Persea americana, p. 253-268. In: A.H. Halevy (ed.). Handbook of flowering, vol. 5, CRC Press, Boca Raton, Fla.

Degani, C. and S. Gazit. 1984. Selfed and crossed proportions of avocado progenies produced by caged pairs of complementary cultivars. HortScience 19(2):258-260.

Degani, C., A. Goldring, S. Gazit, and U. Lavi. 1986. Genetic selection during the abscission of avocado fruitlets. HortScience 21(50:1187.

Goldring. A., D. Zamir, and C. Degani. 1985. Duplicated phosphoglucose isomerase genes in avocado. Theor. Applied Genet. 71:491-494.

Goldring. A., S. Gazit. and C. Degani. 1987. Isozyme analysis of mature avocado embryos to determine outcrossing rate in a 'Hass' plot. J. Amer. Soc. Hort. Sci. 112:389-392

Hackett, W.P. 1985. Juvenility, maturation and rejuvenation in woody plants. Hort. Rev. 7:109-155.

Hansche, P.E. 1983. Response to selection. p 154-171. In: J.N. Moore and J. Janick (eds.). Methods in fruit breeding. Purdue Univ. Press, West Lafayette, Ind. Hansche, P.E. and W. Beres. 1980. Genetic remodeling of fruit and nut trees to facilitate cultivar development. HortScience 15:710-715.

Johnson, H. 1940. Hereditary precocious flowering in Betula verrucosa and B. pubescens. Hereditas 35:112-114.

Lahav, E.. D. Zamet, S. Gazit, and U. Lavi. 1986. Girdling as a means of shortening the juvenile period of avocado seedlings. HortScience 21:1038-1039.

Lavi, E., E. Lahav, A. Genizi, C. Degani, S. Gazit. and J. Hillel. 1991. Quantitative genetic analysis of traits in avocado cultivars. Plant Breeding 106:149-60.

Sanchez Colin, S., A.F. Barrientos Priego, and J.J. Aguilar Melchor. 1990. Avances en el proyecto induccion de fructificación en una huerta-vivero de aguacate. Memoria, Centro de Invest. Cientificas y Tec. del Aguacate en el Estado de Mexico, p. $101-105$.

SAS User's Guide: Statistics. 1985. SAS Institute, Box 8000, Cary, N.C.

Schaffalitzky de Muckadell, M. 1959. Juvenile stages in woody plants. Physiol. Plant. 7:782-796.

Sedgley, A. and D.Mc.E. Alexander. 1983. Avocado breeding research in Australia. Calif. Avocado Soc. Yearbook. 67:129-140.

Sherman, W.B. and P.N. Lyrene. 1983. Handling seedling populations, p. 66-73. In: J.N. Moore and J. Janick (eds.). Methods in fruit breeding. Purdue Univ. Press, West Lafayette, Ind.

Sweet, G.B. and L.G. Wells. 1974. Comparison of the growth of vegetative propagules and seedlings of Pinus radiata. N.Z. J. Sci. 4:399-409.

Torres, A.M., U. Diedenhofen, B.O. Bergh, and R. Knight. 1978. Enzyme polymorphism as genetic markers in the avocado. Amer. J. Bot. 65:134-139.

Visser, T., J.J. Verhaegh, and D.P. de Vries. 1976. A comparison of apple and pear seedlings with reference to the juvenile period. I. Seedling growth and yield. Acta Hort. 56:205-214. 